DOI: $10.17805 /$ zpu.2017.3.6

\title{
Общенациональная и этническая идентичность молодежи этнических групп республик Сибири в сравнительной перспективе *
}

\author{
С. А. МАДЮКОВА, О. А. ПЕРСИДСКАЯ \\ ИНСТИТУТ ФИЛОСОФИИ И ПРАВА СИБИРСКОГО ОТДЕЛЕНИЯ РОССИЙСКОЙ АКАДЕМИИ НАУК, \\ Ю. В. ПОПКОВ \\ ИНСТИТУТ ФИЛОСОФИИ И ПРАВА СИБИРСКОГО ОТДЕЛЕНИЯ РОССИЙСКОЙ АКАДЕМИИ НАУК, \\ НОВОСИБИРСКИЙ ГОСУДАРСТВЕННЫЙ ТЕХНИЧЕСКИЙ УНИВЕРСИТЕТ
}

В статье дается характеристика состояния общенациональной и этнической идентичностей в их соотношении как между собой, так и с региональным и макрорегиональным видами идентичности у молодежи разных национальностей в четырех полиэтничных республиках Сибири (Алтай, Тува, Хакасия, Якутия). Материалом выступили данные этносоциологических исследований коллектива ученых Института философии и права СО РАН в 2000-2010 гг.

Зафиксирована актуальность этнической идентичности наряду с общенациональной (гражданской) идентичностью как важного условия благополучного развития России. Выявлена специфика идентификационных стратегий молодежи в республиках в зависимости от принадлежности к конкретной этнической группе. Проведен анализ идентификационных стратегий в гендерном аспекте, а также анализ распределений ответов контрольной группы респондентов более старших возрастов в Республике Саха (Якутия) с целью сравнительной оценки степени выраженности разных видов идентичности.

В большей степени выраженным видом идентичности является общенациональная (число тех, для кого этот вид идентичности не является важным, не превышало 7\% в каждой из республик). Другие виды идентичности также достаточно востребованы среди молодежи, хотя и выражены в несколько меньшей степени. Исключение составляет Тува, где региональная и этническая идентичности по значимости практически совпадают с общенациональной. Отмечается достаточно сбалансированная структура идентификационной матрицы молодежи. Она выражается в умеренной степени актуальности этнической, макрорегиональной и региональной идентичности при общем доминировании общенацио-

* Работа выполнена по проекту «Влияние этнокультурного неотрадиционализма на формирование общенациональной и этнической идентичности» в рамках Комплексной программы Сибирского отделения Российской академии наук № II.2.

The research is carried out according to the project "The Influence of Neocultural Traditionalism on the Formation of Nationwide and Ethnic Identity" within the Complex programme of the Siberian Branch of the Russian Academy of Sciences No. II.2. 
нальной. Особо акцентируется бесконфликтное сосуществование этнической и общенациональной идентичностей в массовом сознании жителей республик.

Сделан вывод, что относительное благополучие этносоциальной ситуации и межэтнических отношений в исследуемых республиках достигается, в том числе, благодаря наличию баланса разных видов идентичностей. Это создает важные предпосылки оптимального развития региональных межэтнических сообществ в рамках единого Российского государства. Показано, что рассматриваемые виды социальной идентичности не противоречат друг другу в сознании их носителей, а гармоничное развитие межэтнических сообществ исследуемых регионов возможно на основе их одновременного позитивного стимулирования, что представляется важной для современной социокультурной действительности Российской Федерации политической задачей.

Ключевые слова: общенациональная идентичность; этническая идентичность; макрорегиональная идентичность; региональная идентичность; Республика Алтай; Республика Тыва; Республика Хакасия; Республика Саха (Якутия); региональные межэтнические сообщества; этносоциологическое исследование

\section{ИАЕНТИЧНОСТЬ КАК ГАОБАИЬНАЯ И АОКАИЬНАЯ ПРОБАЕМА}

$\Pi$ роблема идентичности в настоящее время выступает одной из наиболее актуальных практически-политических и научных проблем. Примечательно, что в условиях существующей нелинейной социокультурной динамики сам феномен идентичности превратился в весьма подвижную, постоянно меняющуюся и проблематизируемую величину (Федотова, 2013). Не случайно распространенными стали представления о текучей, множественной, раздробленной, договорной идентичности (Брубейкер, 2012). Соответственно возникло большое количество концепций идентичности среди российских и зарубежных исследователей. И хотя в широком потоке дискуссий об идентичности существует критическое отношение не только ко многим ее концепциям, но и к самому данному понятию, есть все основания признать, что идентичность «приобрела значение решающего фактора жизни человека в современном обществе, подверженном риску, неопределенности, кризису и изменениям» (Сморгунов, 2012: 178), и что в настоящее время «в теориях идентичности стали видеть универсальный неинструментальный аппарат анализа ценностных ориентаций, культурного сходства и различия обществ, стран, цивилизаций, больших и малых социальных групп, индивидов» (Федотова, 2013: 55).

В ряду многочисленных видов идентичности фундаментальное значение имеют общенациональная (гражданская) и этническая идентичности. При этом в современном социогуманитарном дискурсе актуализация этнической идентичности нередко преАставляется как противоречащая формированию полноценной общенациональной идентичности и как оказывающая негативное влияние на целостность отдельных государств. Подобные опасения испытывают многие современные страны мира, включая наиболее развитые. Например, знаменитый С. Хантингтон прогнозировал в ближайшей перспективе распад США (Хантингтон, 2008: 33-34).

Применительно к России проблема соотношения данных видов идентичности особенно актуальна для национальных республик, поскольку «в настоящее время сформировались основания институционализации новой позиции российских этносов и республик, образованных на их основании: произошло изменение правового статуса республик в составе РФ, избрание в них президентов, утверждение конституций, подписание федеративного договора и целого ряда двусторонних договоров между субъектами Федерации и федеральным центром, принятие законов о языках и об образовании» (Ноянзина и др., 2015: 201). Значимым в данном контексте представляет- 
ся тот факт, что в Конституции Российской Федерации республики называются государствами: «Республика (государство) имеет свою конституцию и законодательство» (ст. 5, п. 2). «Существующее положение федерального устройства РФ не имеет аналогов в современной мировой практике. Ни в одной из существующих ныне стран, кроме России, национальные автономии не наделены статусом государства» (Багдасарян, 2008: 134-135). Аанное обстоятельство усложняет и в известном смысле запутывает проблемную ситуацию. Но очевидно, что решение задачи разработки и реализации программы формирования в России гражданской идентичности «требует учета не только современной социально-политической ситуации и характера межэтнических отношений, но и факторов формирования этнической идентичности культурных групп населения России» (Шергалиева, 2014: 103).

Значимость этнической идентичности наряду с общенациональной (гражданской) идентичностью как важного условия благополучного развития России имплицитно содержится в важных государственных документах. В частности, об этом, на наш взгляд, свидетельствуют следующие положения Конституции Российской Федерации: «Мы, многонациональный народ Российской Федерации... сохраняя исторически сложившееся государственное единство, исходя из общепризнанных принципов равноправия и самоопределения народов» (Конституция ... : Электронный ресурс), а также Стратегии государственной национальной политики Российской Федерации до 2025 г., в которой говорится о необходимости сочетания общегосударственных интересов и интересов народов России, об активизации всестороннего сотрудничества народов Российской Федерации, развитии их национальных языков и культур (п. 2, раздел I «Общие положения», см.: Указ Президента ..., 2012: Электронный ресурс). Стоит согласиться с известным политиком и ученым Р. Г. Абдулатиповым, что оптимальный вариант процесса формирования политической нации возможен только на основе свободного развития каждого этноса в своей самобытности (Абдулатипов, 2003: Электронный ресурс).

С учетом зафиксированной проблемной ситуации в настоящей статье ставится цель провести анализ состояния общенациональной и этнической идентичностей, как они представлены в массовом сознании разных этнических групп. В качестве объекта исследования определены национальные республики азиатской части России - Алтай, Хакасия, Тыва и Саха (Якутия), которые в комплексе, насколько известно авторам, до сих пор не рассматривались в выделенном аспекте. Акцент делается, во-первых, на оценке состояния и соотношении данных видов идентичности между собой, а также на их сравнительной характеристике с региональным и макрорегиональным видами идентичности, во-вторых, на молодежных группах населения.

Изучение идентификационных стратегий молодежи, представляющей различные социально-территориальные и межэтнические сообщества, особо актуально, поскольку позволяет выявить ориентиры той части населения, от которой во многом зависит будущее региона. Существующий историко-политический контекст развития России формирует запрос на конкретные знания об изменениях, происходящих в молодежной среде и современном ценностном запросе, который формируется у нынешней молодежи в отношении разных видов идентичности в аспекте этнических различий. Важно уловить уже происходящие и грядущие изменения в их миропонимании, осознании своей принадлежности к этносу, региону, стране. Академический интерес представляет анализ изменений идентификационных стратегий, происходящих на фоне глобализации и фрагментации, а также прогнозирование тенденций дальней- 
шей трансформации комплекса социальных идентичностей населения национальных республик.

Эмпирическим материалом для анализа выступили результаты массовых опросов, проведенных в указанных субъектах Федерации сотрудниками сектора этносоциальных исследований Института философии и права Сибирского отделения Российской академии наук в рамках широкой программы изучения современных ценностных ориентаций населения (руководитель общего проекта и коллектива по разработке программы данного исследования - Ю. В. Попков, организаторы опросов в республиках - М. А. Абрамова, С. А. Мадюкова). В опросе задействованы представители учащейся и работающей групп молодежи, преимущественно в возрасте от 14 до 30 лет. Исследование проводилось в конце 2000-х — начале 2010-х годов. Всего опрошено более 5,5 тыс. человек. В каждой из республик в качестве респондентов выступили представители молодежи русской и титульной национальностей, а также коренных малочисленных народов Севера. Аанная статья впервые обобщает информацию проведенного этносоциологического исследования по заявленной теме.

Каждый из исследуемых регионов - республики Алтай, Тыва, Хакасия и Якутия является полиэтничным субъектом РФ, где на одной территории проживают представители разных этнических групп. В Республике Алтай это русские $(56 \%$ населения), алтайцы (32\%), казахи (6\%). Кроме того, жителями региона являются представители коренных малочисленных народов Севера - теленгиты, тубалары, телеуты, челканцы и кумандинцы, составляющие вместе около 4\% от числа жителей республики. Республика Тыва - уникальный сибирский регион в том смысле, что подавляющее большинство (81\% на 2010 г.) здесь составляют тувинцы - титульное население. Русских в Туве меньше, чем в любом другом сибирском регионе, - около $16 \%$. В горнотаежной части на северо-востоке и юго-востоке республики проживают тувинцы-тоджинцы - субэтническая группа тувинцев, отнесенная к числу коренных малочисленных народов Севера. В Республике Хакасия, по данным Всероссийской переписи населения 2010 г., 82\% жителей региона составляют русские, 12\% хакасы, по 1\% немцы и украинцы. В Республике Саха (Якутия) 49\% населения составляют якуты, $39 \%$ - русские, более 4\% составляют представители коренных малочисленных народов Севера (эвенки, эвены, юкагиры, чукчи, долганы) больше половины из которых эвенки $(2,2 \%)$.

\section{СОЦИААЬНЫЕ ИАЕНТИЧНОСТИ}

В данной статье исследовательское внимание фокусируется на групповых (социальных) формах идентичности, которые выступают продуктом процесса социальной идентификации, в результате которого личность осознает себя принадлежащей к той или иной группе. Категоризация групп, сопутствующая процессу социальной идентификации личности, направлена на заострение различий между категориями и их смягчение между элементами внутри одной категории, так формируются группы «своих» и «чужих» (Микляева, Румянцева, 2008: 11). Осознание личностью своей социальной идентичности проходит через обращение к себе как к наследнику и носителю определенных черт характера, традиций, ценностей, особенностей культурно-исторического развития той или иной социальной группы. Становление социальной идентичности формирует у личности восприятие себя в составе целого и отражается в особенностях мироощущения, мировоззрения, эмоционального склада, поведения, специфике коммуникативных актов (Барсукова, Романенко, 2012: 193). 
Сложная система, которую представляют собой разные виды социальных идентичностей личности, отражает ее принадлежность к разным социальным группам. Структура системы социальных идентичностей многомерна. В фокусе нашего исследования находятся лишь некоторые ее компоненты: общенациональная (гражданская) и этническая, а также, в сопоставительном ключе, макрорегиональная (выраженная «сибирским» измерением) и региональная (республиканская) идентичности. Разнообразие перечисленных видов идентичности и сила их выраженности в сознании носителей может стать как основанием для гармоничных взаимоотношений между людьми, так и причиной противоречий и конфликтов на уровне государств, народов, регионов и др. Согласимся с О. Богатовой в признании того, что «одна из актуальных проблем современного российского общества, как и других полиэтничных и мультикультурных сообществ, заключается в интеграции различных в этническом и культурном отношении социальных групп при сохранении существующего этнокультурного многообразия и гарантий как коллективных, так и личных культурных и социальных прав» (Богатова, 2011: 110).

В данной статье понятие общенациональной идентичности рассматривается как синонимичное гражданской идентичности. Как отмечает Е. А. Кочина, «наиболее распространенная интерпретация термина гражданская идентичность в отечественной социологической литературе рассматривается как осознание собственной причастности к сообществу граждан определенного государства» (Кочина, 2015: 255). Общенациональная (гражданская) идентичность является фактором, консолидирующим массовое сознание вокруг интересов страны, поэтому высокая степень выраженности данного компонента является залогом политической и духовной консолидации и единства национальной (в смысле общенациональной, политической) общности (Санина, 2010: 282). Аостаточно распространенным в качестве базового идентифицирующего механизма гражданской идентичности признается патриотизм, чувство гордости за свою страну (Кочина, 2015: 256).

Этническая идентичность представляет собой разновидность социальной идентичности личности и выражает осознанную принадлежность ее к определенной этнической общности как «результат когнитивно-эмоционального процесса осознания себя представителем определенного этноса на основе отождествления с ним и дифференциации от других этносов», как продукт переживания личностью «тождества с одной этнической общностью и отделения от других» (Шергалиева, 2014: 103); она может иметь и положительную, и отрицательную окраску, т. е. в реальности существует позитивная и негативная этническая идентичность. При низком уровне межэтнической напряженности этническая идентичность чаще всего выражается в форме этнопатриотизма, однако при усложнении ситуации она может принять форму национализма и стать причиной межэтнических и межнациональных конфликтов. Важно отметить, что чувство этничности бывает обострено у недоминирующих общностей (Волкогонова, Татаренко, 2001: 151). Устойчивость этнической идентичности во многом связана с тем, что она является формой проявления аффилиативной потребности и в этом качестве взаимосвязана как со специфическими человеческими потребностями, в частности с потребностью в нормативном регулировании, так и с базовыми витальными потребностями в виде потребности в безопасности, самосохранении (Аолженкова, Попков, 2016).

Основанием макрорегиональной идентичности, в качестве которой в нашем случае рассматривается сибирская идентичность, является не только принадлежность к оп- 
ределенной территории. А. А. Анисимова и О. Г. Ечевская отмечают, что к способам интерпретации дефиниции «сибиряки» можно отнести региональную (сибиряки те, кто родился и долго живет в Сибири), культурно-историческую (сибиряки коренные, местные жители Сибири), психологическую (сибиряки - особые по складу здоровья, характера и ума люди) и этническую (сибиряки - смесь нескольких этносов, среди которых русские, украинцы, татары и др.) составляющие. Сибирская компонента идентичности часто проявляется не сама по себе, а в противопоставлении с федеральным центром, олицетворенным в массовом сознании в образе «Москвы»: «...нарративы жителей Сибири, полученные в ходе исследования, демонстрируют важность самоидентификации “сибиряк" в контексте осознаваемых различий между европейской Россией, Москвой и “тем, что за Уралом”, - азиатской Россией и Сибирью. Эти различия касаются прежде всего отношения центра к сибирской территории, к способам ее освоения, которые часто описываются информантами в терминах отношений между метрополией и колониями» (Анисимова, Ечевская, 2012: 76-77).

Регионально-территориальная идентичность, выражающая принадлежность личности к своей республике, округу или области, отражает моменты, связанные с единством территории, общими чертами социально-экономических условий жизни, некоторыми разделяемыми этнокультурными особенностями, а также элементами рефлексии регионального политического процесса. Аанный компонент системы идентичностей часто ассоциируется с понятием «махая родина» и рассматривается в качестве основы формирования местного патриотизма (Алаудинов, 2014: 137). В то же время региональная идентичность может выступать инструментом политики регионализма «как стратегия территорий, направленная на защиту собственных интересов» (Аенисова, 2010: 83).

\section{ОБЩАЯ ХАРАКТЕРИСТИКА СООТНОШЕНИЯ РАЗНЫХ ВИАОВ ИАЕНТИЧНОСТИ СРЕАИ МОАОАЕЖИ В РЕСПУБАИКАХ}

Идентификационные стратегии молодежи были проанализированы на основе ответов на вопрос о степени важности для респондентов осознавать себя гражданином России (на этой основе оценивалась общенациональная, гражданская идентичность), представителем своего народа, этноса (этническая идентичность), сибиряком (макрорегиональная идентичность) и жителем своей республики (региональная идентичность). Так как структура идентичности многомерна и в ней в системном виде присутствуют одновременно несколько составдяющих, респондентам в ходе исследования предлагалось не проводить ранжирование того, что характеризует разные виды идентичности, или выбирать какие-либо альтернативы из них, а оценить степень важности ощущения себя соответственно россиянином, сибиряком, преАставителем своей национальности и жителем республики. В анкету были заложены три варианта возможных ответов на эти вопросы - «очень важно», «важно» и «не важно».

Статистический анализ общих распределений по четырем массивам (табл. 1) показывает, что в большей степени выраженным видом идентичности является общенациональная (гражданская): от $59 \%$ до 69\% респондентов указали, что им очень важно осознавать себя гражданином России. Обратим также внимание на минимальное число тех, для кого этот вид идентичности не является важным: об этом заявили лишь от $3 \%$ до 7\% респондентов во всех республиках, где проведены опросы. 
Таблииа 1

ОБЩАЯ ХАРАКТЕРИСТИКА СТЕПЕНИ ВЫРАЖЕННОСТИ РАЗНЫХ ВИАОВ ИАЕНТИЧНОСТИ У МОАОАЕЖИ В РЕСПУБАИКАХ, \%

Table 1

GENERAL CHARACTERISTICS OF DIFFERENT LEVELS OF IDENTITY AMONG YOUNG PEOPLE

LIVING IN THE REPUBLICS, IN \%

\begin{tabular}{|c|c|c|c|c|c|}
\hline $\begin{array}{c}\text { Вьражен- } \\
\text { ность } \\
\text { идентич- } \\
\text { ности }\end{array}$ & Республики & $\begin{array}{c}\text { Этническая } \\
\text { идентичность }\end{array} \mid$ & $\begin{array}{l}\text { Региональная } \\
\text { идентичность }\end{array}$ & $\begin{array}{c}\text { Макрорегио- } \\
\text { нальная } \\
\text { (сибирская) } \\
\text { идентичность }\end{array}$ & $\begin{array}{c}\text { Общеначио- } \\
\text { нальная } \\
\text { идентичность }\end{array}$ \\
\hline $\begin{array}{l}\text { Очень } \\
\text { важно }\end{array}$ & $\begin{array}{l}\text { Республика Алтай } \\
\text { Республика Тыва } \\
\text { Республика } \\
\text { Хакасия } \\
\text { Республика Саха } \\
\text { (Якутия) }\end{array}$ & $\begin{array}{l}43 \\
58 \\
\\
34 \\
\\
36\end{array}$ & $\begin{array}{l}33 \\
60 \\
22 \\
\\
34\end{array}$ & $\begin{array}{l}27 \\
22 \\
27 \\
7\end{array}$ & $\begin{array}{l}69 \\
59 \\
60 \\
56\end{array}$ \\
\hline Важно & $\begin{array}{l}\text { Республика Алтай } \\
\text { Республика Тыва } \\
\text { Республика } \\
\text { Хакасия } \\
\text { Республика Саха } \\
\text { (Якутия) }\end{array}$ & $\begin{array}{l}38 \\
34 \\
42 \\
42\end{array}$ & $\begin{array}{l}39 \\
30 \\
39 \\
39\end{array}$ & $\begin{array}{l}41 \\
48 \\
46 \\
40\end{array}$ & $\begin{array}{l}28 \\
36 \\
34 \\
37\end{array}$ \\
\hline $\begin{array}{c}\text { Не } \\
\text { важно }\end{array}$ & $\begin{array}{l}\text { Республика Алтай } \\
\text { Республика Тыва } \\
\text { Республика } \\
\text { Хакасия } \\
\text { Республика Саха } \\
\text { (Якутия) }\end{array}$ & $\begin{array}{c}19 \\
9 \\
24 \\
21\end{array}$ & $\begin{array}{l}27 \\
10 \\
39 \\
27\end{array}$ & $\begin{array}{l}32 \\
30 \\
27 \\
64\end{array}$ & $\begin{array}{l}3 \\
4 \\
7\end{array}$ \\
\hline
\end{tabular}

Аругие виды идентичности также достаточно востребованы среди молодежи, хотя и выражены в несколько меньшей степени. Исключение составляет Тува, в которой около $60 \%$ принявших участие в опросе указали, что для них очень важно ощущать себя и жителем своей республики, и представителем своего этноса, т. е. здесь данные виды идентичности по значимости практически совпадают с общенациональной идентичностью.

Можно говорить об умеренной степени выраженности этнической идентичности в республиках Алтай, Хакасия и Саха и региональной идентичности на Алтае и в Якутии. Менее прочих выражена у опрошенных макрорегиональная (сибирская) идентичность, которая для большинства проживающих на Алтае, в Туве и Хакасии скорее важна, нежели очень важна (от $41 \%$ до $48 \%$ ), а для $64 \%$ респондентов из Якутии даже вовсе не важна. Заметим, что в свое время Сибирью считалась вся территория Советского Союза восточнее Урала. В настоящее время, особенно с введением в России федеральных округов, представление о Сибири изменилось - институционально оно значительно сузилось в связи с выделением Сибирского федерального округа. Республика Саха (Якутия) входит в состав Аальневосточного федерального округа. Несмотря на это, мы посчитали целесообразным задать вопрос о сибирской идентич- 
ности, в том числе, и жителям Якутии. Полученные результаты исследования среди молодежи по данному вопросу свидетельствуют о доминировании современных взглядов на макрорегиональное деление России.

Представленные данные позволяют сделать общий вывод о том, что отмеченное сочетание выраженности разных видов идентичности - умеренная степень актуальности этнической, макрорегиональной и региональной идентичности при общем почти для всех опрошенных доминировании общенациональной идентичности - свидетельствует о достаточно сбалансированной структуре идентификационной матрицы молодежи.

\section{ИАЕНТИФИКАЦИОННЫЕ СТРАТЕГИИ ЭТНИЧЕСКИХ ГРУПП МОАОАЕЖИ}

\section{В РЕСПУБАИКАХ}

Аалее дадим более конкретный анализ состояния и соотношения разных видов идентичности в рассматриваемых республиках применительно к разным этническим группам, сделав акцент на тех моментах, которые характеризуются значимыми различиями по этим группам.

Республика Алтай. Аля респондентов-алтайцев в большей степени, чем для опрошенных русских, имеют значение этническая и региональная идентичности (табл. 2). Так, очень важно осознавать себя представителем своего этноса 58\% алтайцев и $37 \%$ русских, а жителем республики - $61 \%$ алтайцев и всего $21 \%$ русских. Почти $40 \%$ русских однозначно заявляют, что республиканская идентичность для них не важна, в то время как подобный ответ дают всего 6\% алтайцев. Как представляется, отмеченные различия связаны прежде всего с тем, что региональность в данном случае институционализирована в виде Республики Алтай, названной не только по причине существующих здесь Алтайских гор, но и с учетом коренных для данной республики жителей - алтайцев. Именно статус титульной национальности делает этническую и региональную идентичность столь значимой для алтайцев (аналогичная ситуация, как покажет дальнейший анализ, имеет место и в других республиках). У русских респондентов в регионе сравнительно более выражена сибирская идентичность - как очень важную Аля себя ее выделили 32\% русских и всего $19 \%$ алтайцев. Общенациональная идентичность в сравнительном ключе более важна для русских жителей региона:

Таблича 2

СТЕПЕНЬ ВЫРАЖЕННОСТИ ЭТНИЧЕСКОЙ, РЕГИОНААЬНОЙ И ОБЩЕНАЦИОНААЬНОЙ ИАЕНТИЧНОСТЕЙ У ПРЕАСТАВИТЕАЕЙ РАЗНЫХ ЭТНИЧЕСКИХ ГРУПП В РЕСПУБАИКЕ ААТАЙ, \%

Table 2

LEVELS OF ETHNIC, REGIONAL AND NATIONWIDE IDENTITY AMONG REPRESENTATIVES OF DIFFERENT ETHNIC GROUPS IN THE ALTAI REPUBLIC, IN \%

\begin{tabular}{|c|c|c|c|c|c|c|}
\hline \multirow{2}{*}{$\begin{array}{l}\text { Выраженность } \\
\text { идентичности }\end{array}$} & \multicolumn{2}{|c|}{$\begin{array}{c}\text { Этническая } \\
\text { идентичность }\end{array}$} & \multicolumn{2}{|c|}{$\begin{array}{l}\text { Региональная } \\
\text { идентичность }\end{array}$} & \multicolumn{2}{|c|}{$\begin{array}{c}\text { Общеначиональная } \\
\text { идентичность }\end{array}$} \\
\hline & алтайщъь & русские & алтайц̧ь & русские & алтайцьь & русские \\
\hline Очень важно & 58 & 37 & 61 & 21 & 65 & 72 \\
\hline Важно & 30 & 39 & 33 & 40 & 34 & 25 \\
\hline Не важно & 12 & 23 & 6 & 39 & 1 & 3 \\
\hline
\end{tabular}


$72 \%$ из них отметили ее как очень важную для себя. Алтайцы чуть более сдержаны в оценках: $65 \%$ отметили ее как очень важную, тогда как вариант «важно» выбрали $34 \%$ из них (русские - 25\%). Как представляется, такое распределение может быть связано с отождествлением русскими себя со страной в целом в большей степени, чем алтайцами, для которых по причинам, описанным выше, не менее значима региональная и этническая идентичности.

Республика Тъıа. Разные этнические группы опрошенных здесь также демонстрируют значительные различия в идентификационных установках. Как и в Республике Алтай, у представителей титульной национальности - тувинцев - этническая и особенно региональная идентичности существенно сильнее проявлены по сравнению с русскими (табл. 3). При этом региональная идентичность тувинцев обратно пропорциональна выраженности того же показателя у русских респондентов.

Общенациональная идентичность отличается в целом высокими показателями у обеих этнических групп, однако есть и различия: очень важно ощущать себя гражданином России для 58\% тувинцев и $69 \%$ русских.

Республика Хакасия. Здесь ситуация аналогичная описанной по предыдущим республикам, а именно существуют различия в оценке значимости этнической и региональной идентичности у представителей разных этнических групп (табл. 4, см. с. 78). Обратим внимание, что в Хакасии очень высок процент русских респондентов, открыто заявляющих о неважности осознания себя в качестве представителя определенного этноса и жителя своего региона. Возможно, данный факт связан с тем, что регион сравнительно недавно получил статус именно национальной республики (до 1991 г. она входила в состав Красноярского края как Хакасская автономная область), и русские как нетитульное население (титульное - хакасы) составляют большинство в регионе, что способствует отождествлению ими себя с русскими России в целом и доминированию у русских респондентов региона общегосударственной идентичности над региональной и этнической.

Что касается общенациональной идентичности, то здесь различий практически не существует: $58 \%$ хакасов и $61 \%$ русских считают для себя очень важным осознавать себя гражданином России и лишь незначительное число опрошенных (соответственно $3 \%$ и $7 \%$ ) отмечают, что это для них не важно.

СТЕПЕНЬ ВЫРАЖЕННОСТИ ЭТНИЧЕСКОЙ, РЕГИОНААЬНОЙ

Таблища 3

И ОБЩЕНАЦИОНАЦЬНОЙ ИАЕНТИЧНОСТЕЙ У ПРЕАСТАВИТЕ ЕЙ РАЗНЫХ ЭТНИЧЕСКИХ ГРУПП В РЕСПУБАИКЕ ТЫВА, \%

Table 3

LEVELS OF ETHNIC, REGIONAL AND NATIONWIDE IDENTITY AMONG REPRESENTATIVES OF DIFFERENT ETHNIC GROUPS IN THE TYVA REPUBLIC, IN \%

\begin{tabular}{|c|c|c|c|c|c|c|}
\hline \multirow{2}{*}{$\begin{array}{l}\text { Выраженность } \\
\text { идентичности }\end{array}$} & \multicolumn{2}{|c|}{$\begin{array}{c}\text { Этническая } \\
\text { идентичность }\end{array}$} & \multicolumn{2}{|c|}{$\begin{array}{l}\text { Региональная } \\
\text { идентичность }\end{array}$} & \multicolumn{2}{|c|}{$\begin{array}{c}\text { Общеначиональная } \\
\text { идентичность }\end{array}$} \\
\hline & тувинцьь & русские & тувинизь & русские & тувиниьь & русские \\
\hline Очень важно & 61 & 44 & 69 & 15 & 58 & 69 \\
\hline Важно & 33 & 43 & 29 & 41 & 38 & 25 \\
\hline Не важно & 7 & 14 & 5 & 44 & 4 & 6 \\
\hline
\end{tabular}




\section{СТЕПЕНЬ ВЫРАЖЕННОСТИ ЭТНИЧЕСКОЙ, РЕГИОНААЬНОЙ И ОБЩЕНАЦИОНААЬНОЙ \\ Таблища 4 ИАЕНТИЧНОСТЕЙ У ПРЕАСТАВИТЕАЕЙ РАЗНЫХ ЭТНИЧЕСКИХ ГРУПП В РЕСПУБАИКЕ ХАКАСИЯ, \%}

Table 4

LEVELS OF ETHNIC, REGIONAL AND NATIONWIDE IDENTITY AMONG REPRESENTATIVES OF DIFFERENT ETHNIC GROUPS IN THE REPUBLIC OF KHAKASSIA, IN \%

\begin{tabular}{|c|c|c|c|c|c|c|}
\hline \multirow{2}{*}{$\begin{array}{l}\text { Выраженность } \\
\text { идентичности }\end{array}$} & \multicolumn{2}{|c|}{$\begin{array}{c}\text { Этническая } \\
\text { идентичность }\end{array}$} & \multicolumn{2}{|c|}{$\begin{array}{l}\text { Региональная } \\
\text { идентичность }\end{array}$} & \multicolumn{2}{|c|}{$\begin{array}{c}\text { Общеначиональная } \\
\text { идентичность }\end{array}$} \\
\hline & хакасы & русские & хакасы & русские & хакасы & русские \\
\hline Очень важно & 48 & 29 & 52 & 14 & 58 & 61 \\
\hline Важно & 43 & 43 & 41 & 36 & 39 & 32 \\
\hline Не важно & 8 & 28 & 8 & 52 & 3 & 7 \\
\hline
\end{tabular}

Республика Саха (Якутия). Общенациональная идентичность в большей мере актуализирована (как очень важная) у русских (72\%). Представители других этнических групп более сдержанны в оценках: заявляют, что им очень важно ощущать себя гражданином Российской Федерации, 47\% якутов, 52\% представителей коренных малочисленных народов Севера (КМНС). Важным этот вид идентичности для себя называют $46 \%$ якутов, $41 \%$ опрошенных их числа малочисленных народов и $23 \%$ русских.

Этническая и региональная идентичности умеренно выражены у представителей народов Севера, а для значительной доли респондентов из числа русских эти виды идентичности являются не важными (табл. 5.).

Отметим, что идентификация себя как типичного представителя Севера (специальный вид макрорегиональной идентичности, выделенный во время опроса в Якутии) не получила значительного отклика у респондентов в Якутии. Она не важна для 50\% якутов и $61 \%$ русских. Также не актуальной для всех групп опрошенных в Республике Саха оказалась макрорегиональная сибирская идентичность: 62\% якутов, 63\% эвенков,

Таблища 5

СТЕПЕНЬ ВЫРАЖЕННОСТИ ЭТНИЧЕСКОЙ, РЕГИОНААЬНОЙ И ОБЩЕНАЦИОНААЬНОЙ ИАЕНТИЧНОСТЕЙ У ПРЕАСТАВИТЕАЕЙ РАЗНЫХ ЭТНИЧЕСКИХ ГРУПП

В РЕСПУБАИКЕ САХА (ЯКУТИЯ), \%

Table 5

LEVELS OF ETHNIC, REGIONAL AND NATIONWIDE IDENTITY AMONG REPRESENTATIVES OF DIFFERENT ETHNIC GROUPS IN THE SAKHA (YAKUTIA) REPUBLIC, IN \%

\begin{tabular}{|c|c|c|c|c|c|c|c|c|c|}
\hline \multirow{2}{*}{$\begin{array}{l}\text { Вьцаженность } \\
\text { идентичности }\end{array}$} & \multicolumn{3}{|c|}{$\begin{array}{c}\text { Этническая } \\
\text { идентичность }\end{array}$} & \multicolumn{3}{|c|}{$\begin{array}{l}\text { Региональная } \\
\text { идентичность }\end{array}$} & \multicolumn{3}{|c|}{$\begin{array}{c}\text { Общеначиональная } \\
\text { идентичность }\end{array}$} \\
\hline & якутьь & русские & $\mathrm{KMHC}$ & якуть & русские & KMHC & якутьл & русские & $\mathrm{KMHC}$ \\
\hline Очень важно & 41 & 31 & 41 & 51 & 11 & 39 & 47 & 72 & 52 \\
\hline Важно & 45 & 39 & 46 & 41 & 34 & 52 & 46 & 23 & 41 \\
\hline Не важно & 13 & 29 & 13 & 8 & 55 & 9 & 7 & 5 & 8 \\
\hline
\end{tabular}


$64 \%$ русских и $69 \%$ эвенов отметили, что им не важно ощущать себя сибиряком. Аанный факт уже был объяснен выше.

Во время опроса в Республике Саха (Якутия) была опрошена, помимо молодежи, контрольная группа респондентов более старших возрастов с целью сравнительной оценки степени выраженности разных видов идентичности. Проведенный в качестве иллюстрации анализ степени важности общенациональной идентичности для разных возрастных групп показывает, что с увеличением возраста оценка «очень важно ощущать себя гражданином России» сменяется у значительной части опрошенных на более сдержанную «важно ощущать себя гражданином России». Аинамика такова, что в группе респондентов младше 15 лет $69 \%$ выбирают ответ «очень важно» и всего $27 \%$ «важно»; среди тех, кому от 25 до 29 лет, примерно одинаковое число выбирают ответ «очень важно» и «важно»; в группе людей от 30 до 34 лет вариант «важно» начинает преобладать, а в возрастной категории респондентов 35-49 лет снова практически выравнивается разрыв между высокой и сдержанно высокой оценкой значимости общенациональной идентичности.

В ходе исследования был выявлен еще один интересный факт. Анализ идентификационных стратегий в гендерном аспекте показал, что в целом мужчины при оценке степени значимости для себя разных видов идентичности чаще женщин выбирают ответ «очень важно». Проиллюстрируем данный вывод на примере Республике Алтай (отметив, что аналогичные результаты показывают данные опросов и в других республиках). Итак, ответ «очень важно» дают при оценке этнической идентичности $50 \%$ мужчин и $37 \%$ женщин (важно это для $32 \%$ мужчин и $42 \%$ женщин), региональной идентичности - соответственно $39 \%$ мужчин и $30 \%$ женщин (важно - 35\% мужчин и $42 \%$ женщин), макрорегиональной (сибирской) идентичности $-41 \%$ мужчин и $18 \%$ женщин (важно - $35 \%$ мужчин и $42 \%$ женщин). Исключением в данном случае является общенациональная идентичность, одинаково важная как для мужчин, так и для женщин.

В ходе исследования не получило статистического подтверждения предположение, что люди, имеющие разный достаток или проживавшие длительное время в разных условиях (кто провел основную часть жизни в селе, в поселке городского типа и в городе), будут иметь значимые различия в идентификационных стратегиях.

\section{ЗАКАЮЧЕНИЕ}

Результаты проведенного исследования показали, что в большинстве случаев все рассматриваемые виды социальной идентичности в высокой степени выражены у разных этнических групп молодежи республик Сибири. Относительное благополучие этносоциальной ситуации и межэтнических отношений в данных республиках достигается, в том числе, благодаря наличию определенного баланса разных видов идентичностей, прежде всего общенациональной и этнической. Это создает важные предпосылки оптимального развития региональных межэтнических сообществ в рамках единого Российского государства.

В то же время в существующей научной литературе и официальных государственных документах общенациональная (гражданская) и этническая идентичности часто трактуются не как взаимодополняемые, а как конкурирующие, поэтому перспектива развития видится, как правило, в постепенном «вытеснении» этнической идентичности за счет общенациональной. Аостаточно сказать, что в Стратегии государственной национальной политики РФ на период до 2025 г. в качестве определяющей названа 
целевая установка на упрочение общероссийского гражданского самосознания (общенациональной идентичности), об этнической идентичности даже не упоминается, а подспудно она рассматривается как неодобряемое явление. Такой подход нельзя признать оправданным в условиях, когда этническая идентичность продолжает оставаться принципиально важной для доминирующей части населения, поскольку выполняет фундаментальные индивидуально и социально значимые функции, помогает удовлетворять специфические человеческие потребности в нормативном регулировании, безопасности, самосохранении и др., внося серьезный вклад в решение государственной и глобально значимой задачи по сохранению этнокультурного разнообразия российского общества. Это реальность, которая должна быть учтена в практической политике и доктринальных документах, формирующих ее концептуальные основания, в частности в разрабатываемом в настоящее время федеральном законе о государственной национальной политике в Российской Федерации.

\section{СПИСОК АИТЕРАТУРЫ}

Конституция Российской Федерации [Электронный ресурс] // Конституция Российской Федерации. URL: http://www.constitution.ru/ (дата обращения: 15.05.2017).

Указ Президента Российской Федерации от 19.12.2012 г. № 1666 О Стратегии государственной национальной политики Российской Федерации на период до 2025 года (2012) [Электронный ресурс]// Президент России. 19 декабря. URL: http://kremlin.ru/acts/bank/36512 (дата обращения: 15.06.2017).

Абдулатипов, Р. Г. (2003) Создание российской нации (проект для XXI века) [Электронный peсурс]// Российская газета. Федеральный выпуск № 3284. URL: www.rg.ru/2003/08/28/Sozdanierossijskojnatsii.html (дата обращения: 20.05.2017).

Алаудинов, А. А. (2014) Региональная идентичность: понятие, содержание и структура // Перспективы науки. №9 (60). С. 134-137.

Анисимова, А. А., Ечевская, О. Г. (2012) Сибирская идентичность: предпосылки формирования, контексты актуализации. Новосибирск : НГУ. 176 с.

Багдасарян, В. Э. (2008) Проблема региональной дезинтеграции как угроза российской государственности // Проблемы государственной политики регионального развития России. Материалы Всероссийской научной конференции (Москва, 4 апреля 2008 г.). М. : Научный эксперт. C. $134-135$.

Барсукова, Е. Н., Романенко, И. Б. (2012) Социокультурная идентичность и национальный менталитет: урбантропологический подход // Общество. Среда. Развитие. № 4 (25). С. 193-196.

Богатова, О.А. (2011) Этнорегиональная и национально-гражданская идентификация в структуре социальной идентичности населения Республики Мордовия // Власть. №5. C. $110-115$.

Брубейкер, Р. (2012) Этничность без групп / пер. с англ. И. Борисовой. М. : ИзА. дом Высшей школы экономики. 408 с.

Волкогонова, О. А., Татаренко, И. В. (2001) Этническая идентификация русских, или искушение национализмом // Мир России. № 2. С. 149-166.

Аенисова, Г. С. (2010) Структура региональной идентичности городского и сельского населения Ростовской области // Наука и образование: хозяйство и экономика; предпринимательство; право и управление. № 1 (1). С. 82-90.

Аолженкова, О. В., Попков, Ю. В. (2016) Этническая идентичность в контексте теории потребностей // Знание. Понимание. Умение. №2. С. 53-65. DOI: 10.17805/zpu.2016.2.5

Кочина, Е. А. (2015) Гражданская идентичность в полиэтническом регионе как элемент национальной идентичности // Инновационная наука. Т. 2. №6 (6). С. 255-257.

Микляева, А. В., Румянцева, П. В. (2008) Социальная идентичность личности: содержание, структура, механизмы формирования. СПб. : РГПУ. 118 с. 
Ноянзина, О. Е., Максимова, С. Г., Авдеева, Г. С., Омельченко, А. А., Гончарова, Н. П. (2015) Этническая и гражданская идентичность населения современного региона России // Вестник Алтайского государственного аграрного университета. № 6 (128). С. 200-204.

Санина, А. Г. (2010) Социальные основания гражданской идентичности в современном обществе: субстанциональный, пространственный и деятельностный аспекты // Вестник СанктПетербургского университета. Сер. 12. Вып. 4. С. 281-286.

Сморгунов, $\Lambda$. В. (2012) Политическая идентичность и понятие политического // Политические исследования. №6. С. 178-185.

Федотова, Н. Н. (2013) Концепции идентичности в условиях нелинейной социокультурной динамики // Знание. Понимание. Умение. № 2. С. 52-62.

Хантингтон, С. (2008) Кто мы? Вызовы американской национальной идентичности / пер. с англ. А. Башкирова. М. : АСТ. 635 с.

Шергалиева, М. Т. (2014) К методологии проблемы идентичностей: социальная, личная, этническая и гражданская // Система ценностей современного общества. № 33. С. 100-105.

Аата поступления: 20.07.2017 2.

\section{NATIONWIDE AND ETHNIC IDENTITY OF YOUNG PEOPLE OF ETHNIC GROUPS LIVING \\ IN SIBERIAN REPUBLICS IN A COMPARATIVE PERSPECTIVE \\ S. A. Madyukova, O. A. PeRsidskaya \\ INSTITUTE OF PHILOSOPHY AND LAW, SIBERIAN BRANCH, RUSSIAN ACADEMY OF SCIENCES \\ Y. V. POPKOV \\ Institute of Philosophy and LAW, Siberian BRANCH, RUSSian ACADEMy of SCIENCES; NOVOSIBIRSK STATE TECHNICAL UNIVERSITY}

The paper characterizes the state of the nationwide and ethnic identities in relation to both each other and regional and macroregional identity types of young people of different nationalities in four polyethnic Siberian republics (Altai, Tyva, Khakassia, Yakutia). The material was gathered from the data of the ethnosociological research conducted by a group of scientists from the Institute of Philosophy and Law of the Siberian Branch of the RAS in 2000-2010.

The paper establishes the topicality of ethnic identity alongside nationwide (civil) identity as a major condition for Russia's well-being. It also unravels the specific of youth identity strategies in the republics depending on their particular ethnic group. It analyses the identity strategies in the gender aspect, as well as the answers breakdown by the older reference group of respondents in the Sakha (Yakutia) Republic with the aim of comparative evaluation of the extent to which different types of identity are expressed.

The identity type expressed to the greatest extent is nationwide (the number of people who do not consider this type of identity to be important is 7 per cent or lower in each republic). Other identity types are quite popular with young people as well; however, they are expressed to a lesser extent. The exception is Tyva, where the regional and ethnic identity nearly equal nationwide in importance. A fairly balanced structure of the identity matrix of young people is also noted. It is expressed in a moderate extent of the urgency of ethnic, macroregional, and regional identity, with the overall dominance of nationwide. A special emphasis is placed on the conflict-free coexistence of ethnic and nationwide identities in the mass consciousness of the people living in the republics.

The conclusion is drawn as follows: the comparative well-being of the ethnosocial situation in the republics under research is reached, among other things, by means of the balance of different identity types. It sets important preconditions for optimal development of the regional interethnic communities within the united Russian state. It is shown that the social identity types in question do not contradict one another in their bearers' consciousness, and the harmonious development of the regions under study is possible on the basis of their simultaneous positive stimulation. This appears to be an important political task for the modern sociocultural reality of Russia. 
Keywords: nationwide identity; ethnic identity; macroregional identity; regional identity; the Altai Republic; the Tyva Republic; the Republic of Khakassia; the Sakha (Yakutia) Republic; regional interethnic communities; ethnosociological research

\section{REFERENCES}

Konstitutsiia Rossiiskoi Federatsii. Konstitutsiia Rossiiskoi Federatsii [online] Available at: http://www.constitution.ru/ (access date: 15.05.2017). (In Russ.).

Ukaz Prezidenta Rossiiskoi Federatsii ot 19.12.2012 g. №1666 O Strategii gosudarstvennoi natsional'noi politiki Rossiiskoi Federatsii na period do 2025 goda (2012). Prezident Rossii, 19 December [online] Available at: http://kremlin.ru/acts/bank/36512 (access date: 15.06.2017). (In Russ.).

Abdulatipov, R. G. (2003) Sozdanie rossiiskoi natsii (proekt dlia XXI veka). Rossiiskaia gazeta. Federal'nyi vypusk, no. 3284 [online] Available at: www.rg.ru/2003/08/28/Sozdanierossijskojnatsii.html (access date: 20.05.2017). (In Russ.).

Alaudinov, A. A. (2014) Regional'naia identichnost': poniatie, soderzhanie i struktura. Perspektivy nauki, no. 9 (60), pp. 134-137. (In Russ.).

Anisimova, A. A. and Echevskaia, O. G. (2012) Sibirskaia identicbnost': predposylki formirovaniia, konteksty aktualizatsii. Novosibirsk, NGU. 176 p. (In Russ.).

Bagdasarian, V. E. (2008) Problema regional'noi dezintegratsii kak ugroza rossiiskoi gosudarstvennosti. In: Problemy gosudarstvennoi politiki regional' nogo razvitiia Rossii. Materialy Vserossiiskoi nauchnoi konferentsii (Moskva, 4 aprelia 2008 g. ). Moscow, Nauchnyi ekspert. Pp. 134-135. (In Russ.).

Barsukova, E. N. and Romanenko, I. B. (2012) Sotsiokul'turnaia identichnost' i natsional'nyi mentalitet: urbantropologicheskii podkhod. Obshchestvo. Sreda. Razvitie, no. 4 (25), pp. 193-196. (In Russ.).

Bogatova, O. A. (2011) Etnoregional'naia i natsional'no-grazhdanskaia identifikatsiia v strukture sotsial'noi identichnosti naseleniia Respubliki Mordoviia. Vlast', no. 5, pp. 110-115. (In Russ.).

Brubeiker, R. (2012) Etnichnost' bez grupp / transl. by I. Borisova. Moscow, Izd. dom Vysshei shkoly ekonomiki. 408 p. (In Russ.).

Volkogonova, O. D. and Tatarenko, I. V. (2001) Etnicheskaia identifikatsiia russkikh, ili iskushenie natsionalizmom. Mir Rossii, no. 2, pp. 149-166. (In Russ.).

Denisova, G. S. (2010) Struktura regional'noi identichnosti gorodskogo i sel'skogo naseleniia Rostovskoi oblasti. Nauka i obrazovanie: khoziaistvo i ekonomika; predprinimatel'stvo; pravo i upravlenie, no. 1 (1), pp. 82-90. (In Russ.).

Dolzhenkova, O. V. and Popkov, Iu. V. (2016) Etnicheskaia identichnost' v kontekste teorii potrebnostei. Znanie. Ponimanie. Umenie, no. 2, pp. 53-65. DOI: 10.17805/zpu.2016.2.5 (In Russ.).

Kochina, E. A. (2015) Grazhdanskaia identichnost' v polietnicheskom regione kak element natsional'noi identichnosti. Innovatsionnaia nauka, vol. 2, no. 6 (6), pp. 255-257. (In Russ.).

Mikliaeva, A. V. and Rumiantseva, P. V. (2008) Sotsial' naia identicbnost' licbnosti: soderzbanie, struktura, mekbanizmy formirovaniia. St. Petersburg, RGPU. 118 p. (In Russ.).

Noianzina, O. E., Maksimova, S. G., Avdeeva, G. S., Omel'chenko, D. A. and Goncharova, N. P. (2015) Etnicheskaia i grazhdanskaia identichnost' naseleniia sovremennogo regiona Rossii. Vestnik Altaiskogo gosudarstvennogo agrarnogo universiteta, no. 6 (128), pp. 200-204. (In Russ.).

Sanina, A. G. (2010) Sotsial'nye osnovaniia grazhdanskoi identichnosti v sovremennom obshchestve: substantsional'nyi, prostranstvennyi i deiatel'nostnyi aspekty. Vestnik Sankt-Peterburgskogo universiteta, issue 12, vol. 4, pp. 281-286. (In Russ.).

Smorgunov, L. V. (2012) Politicheskaia identichnost' i poniatie politicheskogo. Politicheskie issledovaniia, no. 6, pp. 178-185. (In Russ.).

Fedotova, N. N. (2013) Kontseptsii identichnosti v usloviiakh nelineinoi sotsiokul'turnoi dinamiki. Znanie. Ponimanie. Umenie, no. 2, pp. 52-62. (In Russ.).

Khantington, S. (2008) Kto my? Vyzovy amerikanskoi natsional'noi identicbnosti / transl. by A. Bashkirov. Moscow, AST. 635 p. (In Russ.). 
Shergalieva, M. T. (2014) K metodologii problemy identichnostei: sotsial'naia, lichnaia, etnicheskaia i grazhdanskaia. Sistema tsennostei sovremennogo obshchestva, no. 33, pp. 100-105. (In Russ.).

Submission date: 20.07.2017.

Мадюкова Светлана Александровна - кандидат философских наук, научный сотрудник сектора этносоциальных исследований Института философии и права СО РАН. Адрес: 630090, Россия, г. Новосибирск, ул. Николаева, А. 8, комн. 408. Тел.: +7 (383) 330-22-40. Эл. адрес: sveiv7@mail.ru

Персидская Ольга Алексеевна - младший научный сотрудник сектора этносоциальных исследований Института философии и права СО РАН. Адрес: 630090, Россия, г. Новосибирск, ул. Николаева, д. 8, комн. 408. Тел.: +7 (383) 330-22-40. Эл. адрес: olga_alekseevna@mail.ru

Попков Юрий Владимирович - доктор философских наук, профессор, заместитель директора по научной работе Института философии и права СО РАН, профессор Новосибирского государственного технического университета. Адрес: 630090, Россия, г. Новосибирск, ул. Николаева, А. 8, комн. 408. Тел.: +7 (383) 330-22-40. Эл. алрес: yuripopkov54@mail.ru

Madyukova Svetlana Aleksandrovna, Candidate of Philosophy, Research Fellow, Institute of Philosophy and Law, Siberian Branch, Russian Academy of Sciences. Postal address: 8, Nikolaeva St., Novosibirsk, Russian Federation 630090.Tel.: +7 (383)330-22-40.E-mail: sveiv7@mail.ru

Persidskaya Olga Alekseevna, Junior Research Fellow, Institute of Philosophy and Law, Siberian Branch, Russian Academy of Sciences. Postal address: 8, Nikolaeva St., Novosibirsk, Russian Federation 630090. Tel.: +7 (383) 330-22-40.E-mail: olga_alekseevna@mail.ru

Popkov Yuriy Vladimirovich, Doctor of Philosophy, Deputy Director for Research, Institute of Philosophy and Law, Siberian Branch, Russian Academy of Sciences; Professor, Novosibirsk State Technical University. Postal address: 8, Nikolaeva St., Novosibirsk, Russian Federation 630090. Tel.: +7 (383) 330-22-40. E-mail: yuripopkov54@mail.ru 